\begin{tabular}{c} 
REVISTA EVIDENCIAÇÃO CONTÁBIL \& FINANÇAS \\
João Pessoa, v.7, n.2, p.142-159, mai./ago. 2019. ISSN 2318-1001 \\
DOI: 10.22478/ufpb.2318-1001.\%Yv\%vn\%i.41238 \\
Disponível em: http://periodicos.ufpb.br/ojs2/index.php/recfin \\
\hline
\end{tabular}

\title{
THE INTEGRATED FINANCIAL REPORTING OF LISTED COMPANIES ON THE STOCK EXCHANGE OF THAILAND ${ }^{1}$
}

\author{
Sarapee Chanatup ${ }^{2}$ \\ Walailak University \\ s chanatup@yahoo.com \\ Somnuk Aujirapongpan \\ Walailak University \\ asomnuk@wu.ac.th \\ Muttanachai Suttipun \\ Songkla University \\ muttanachai.s@psu.ac.th
}

\begin{abstract}
Objective: This study aims to investigate the level and extent to which the International Integrated Reporting Framework is used in the corporate reporting of Listed Companies on the Stock Exchange of Thailand, and to test whether there is a different level of integrated reporting between companies in different industries.
\end{abstract}

Background: Since grouping of ASEAN Economic Community (AEC) which includes ten countries located in Southeast Asia was held, there have been several international standards in terms of accounting and finance used for the member countries including corporate integrated report. There is little evidence indicating the extent and level of integrated reporting guided by the IIRF in Thailand. Consequently, investigating integrated reporting in Thailand could be reporting a guideline for Thai listed companies and the Stock Exchange of Thailand.

Methodology: This study analysed the annual registration statements (Form 56-1) for year-end 2015 of the 139 listed firms. The level of integration was measured with regard to items based on the content analysis of the International Integrated Reporting Framework. Descriptive analysis, ANOVA, and t-test were used to analyse the data of study.

Results: The results reveal a significant variation in the integrated financial reporting scores across various integrated financial reporting items and industries. It is also found that the organizational overview and external environment element, and risk and opportunities element generated the highest scores, whereas the strategy and resource allocation element revealed the lowest scores among the firms. Moreover, the highest score is found in the financial and resource industries, while the technology sector obtained the lowest score. Finally, we found to be significantly different

\footnotetext{
${ }^{1}$ Artigo recebido em: 21/08/2018. Revisado por pares em: 07/10/2018. Reformulado em: 18/02/2019. Recomendado para publicação: 18/02/2019 por Vagner Antônio Marques (Editor Adjunto). Publicado em: 24/05/2019. Organização responsável pelo periódico: UFPB

Endereço: Walailak University 222, Thai Buri, Tha Sala District, Nakhon Si Thammarat 80161, Thailand.
} 
between each pair of industries across the organizational overview and external environment, business model, strategy and resource allocation, performance and future outlook.

Contributions: This study identified the level and extent of the integrated financial reporting in the corporate reporting of listed companies on the Stock Exchange of Thailand. The findings represent fundamental information for the development of the International Integrated Reporting Framework in Thailand.

Keywords: integrated reporting, integrated financial reporting, corporate reporting

\section{INTRODUCTION}

Economic growth and business outcomes have created both positive and negative effects on society (Tilley, 2012). Some of the positive effects include an increased standard of living, better education, and new technology, while the most obvious negative impacts are an increase in pollution and a reduction of natural resources. The direction of the world in the $21^{\text {st }}$ century is, therefore, dictated by population growth, resource scarcity, technological innovation, and climate change (Lynch, Lynch, \& Casten, 2014). Moreover, stakeholders are becoming increasingly aware of the impacts of business activities on environment, society, and economy (Lynch et al., 2014).

As a result, companies are now required to serve all stakeholder groups such as reporting both financial and non-financial information such as forward-looking information, corporate strategy, and sustainability performance (Orens \& Lybaert, 2013). This is because the corporations now understand that providing financial information alone is insufficient for requirements and expectations of stakeholders (Hughen, Lulseged, \& Upton, 2014). As such, corporations now routinely disclose information on aspects of their performance beyond merely financial matters, including environmental performance, social performance, and governance performance (Eccles \& Saltzman, 2011; International Federation of Accountants [IFAC], 2012). In response to this increasing expectation, some leading companies have begun to publish integrated reporting, in the form of a document that provides a coherent overview of both financial and non-financial information (Frias-Aceituno, Rodriguez-Ariza, \& Garcia-Sanchez, 2014) and how this information relates to corporate strategy, corporate governance, and sustainability performance (Tilley, 2012).

The integrated reporting has been in place since 2002, during which time, the relevant definitions, frameworks, and standards have evolved (Eccles \& Serafeim, 2015). The number of corporations applying integrated reporting remained relatively low during the early years, but this was followed by a rapid surge in popularity between 2009 and 2012. However, the level of integrated reporting then went into a period of decline after the International Integrated Reporting Council (IIRC) published a framework in December 2013. It might be that the framework was confusing for the companies (Demirel \& Erol, 2016). The level of adoption of the integrated reporting principle varied widely in developed countries (Demirel \& Erol, 2016). It was just the beginning of permeating through Southeast Asia (e.g., Malaysia, Singapore, and Thailand). Graham (2014) suggested that the integrated reporting identified in developing countries was very necessary to examine the adoption of the principles. In Thailand, the Securities and Exchange Commission announced that all listed companies would be required to integrate financial and non-financial information into their corporate reports in 2015. That is the first step for integrated reporting in Thailand.

However, there is only one study investigating integrated reporting in Thailand (See Suttipun, 2017), while the others emerging economic countries have started to study such as Malaysia (PWC, 2014a; Jamal \& Ghani, 2016), Indonesia (Abdullah, Husin \& Nor, 2017), Bangladesh (Nurunnabi, Hossain \& Hossain, 2001), and Kenya (Abeysekera, 2010). Therefore, there is little 
evidence indicating the extent and level of integrated reporting guided by the IIRF in Thailand. Moreover, since grouping of ASEAN Economic Community (AEC) which includes ten countries located in Southeast Asia was held, there are several international standards in terms of accounting and finance used for the member countries such as the International Financial Reporting Standards (IFRSs), the International Education Standards for Accounting Professions (IES), the ASEAN Corporate Governance (CG) Scorecard, and the corporate integrated report. Due to the limited evidence, Thailand, thus, is the reason of this study to investigate the extent and level of integrated reporting from listed companies in the Stock Exchange of Thailand (SET). This study also tests whether there is a different level of integrated reporting between companies in different industries.

The study provides some expected contributions. For example, firstly, it will develop knowledge and understanding about Thailand which represents an emerging economic country. Secondly, this study will make information available to scholars and researchers about integrated reporting in developing countries which will broaden the knowledge already available about developed countries . Finally, it will contribute useful knowledge to investors, shareholders, and creditors who consider integrated reporting when making investment decisions and may lead to improvements in the Thai regulations relating to integrated reporting with benefits for people, the planet, and profits. The structure of this study begins with literature review detailing background and motivation of integrated reporting. Next, research objectives, questions, and hypothesis development are described the direction of study. Research methodology used in this study is explained into three sub-sections: population and sample; data collection and variable measurement; and data analysis. The findings are shown in the next section. Finally, conclusions and discussions which include implication, limitation, and suggestion for future study are indicated.

\section{LITERATURE REVIEW}

\subsection{Background of Integrated Reporting}

European enterprises were the first to adopt integrated reporting in 2002, followed by American companies in 2008 and South African listed firms in 2010 (Abeysekera, 2013; Eccles \& Saltzman, 2011). However, there remained ambiguity and a lack of clarity over the definitions, framework, and standards of integrated reporting. Some of the international organizations and famous scholars developed different definitions of integrated reporting. For instance, the Integrated Reporting Committee describes integration as "a holistic and integrated representation of a company's performance regarding both finance and sustainability" (Integrated Reporting Committee [IRC], 2011). In addition, the International Integrated Reporting Council defines integrated reporting as "a process founded on integrated thinking that results in a periodic integrated report by an organization about value creation over time and related communications regarding aspects of value creation" (International Integrated Reporting Committee [IIRC], 2013a). An annual integrated report communicates an organization's strategy, governance, performance, and prospects in the external environment (IIRC, 2013a). Robert G. Eccles opined that integrated reporting presents various issues, including social, environmental, and corporate governance, in one amalgamated report (Eccles \& Saltzman, 2011). In summary, it can be concluded that integrated reporting is used as a corporate reporting tool to present information on financial and non-financial performance, including economic, social, environmental, corporate governance, and corporate strategy, all of which holistically affect the organization's future values.

Nowadays, integrated reporting principle is early stages in Southeast Asian.

In Singapore, for instance, an Integrated Reporting Steering Committee (IRSC) was established within the Institute of Singapore Chartered Accountants (ISCA) in 2013. Similarly, IRSC was 
established within the Malaysian Institute of Accountants (MIA) in 2014. Those represent a critical role in developing the integrated reporting in their countries (Abdullah, Husin, \& Nor, 2017). The integrated reporting is still unknown in Malaysia and not yet integrated (Graham, 2014; Jamal \& Ghani, 2016). PWC (2014a) noted that most of the Top 30 companies listed on the Bursa Malaysia have already disclosed at least some of the content elements in the IR Framework. However, there is a lack of linkage between these elements. Also, a survey of the Institute of Singapore Chartered Accountants [ISCA] and National University of Singapore [NUS] (2014) indicated a low level of knowledge about integrated reporting in Singapore, but it was higher than the other Southeast Asian countries. Thailand, whereas, is still voluntary disclosure of integrated financial reporting in Thailand (Suttipun, 2017). Thai listed companies started to integrate financial and non-financial information into their corporate reports in 2015 (Aujirapongpan \& Chanatup, 2015). It is a strategy to draw academic attention.

Although the integration of reporting has been carried out continuously since 2002, a definitive reporting framework is still being developed. The Reporting Council (IIRC) plays a critical role in the development of an integrated reporting framework (IIRF) at the international level (Velte, 2014). The IIRC was formed in 2010 through a partnership between the Prince of Wales Accounting for Sustainability Project and the Global Reporting Initiative (Main \& Hespenheide, 2012). They published their first framework in December 2013. Practitioners should focus on IIRF for the purpose of comparison at that national and international level. Under this framework, the basic concepts and principles of the annual integrated report consist of fundamental concepts, guiding principles, and content elements (IIRC, 2013b). The details are as follows:

Table 1: Summary of International Integrated Reporting Framework

\begin{tabular}{|c|c|c|}
\hline Fundamental Concepts & Guiding Principles & Content Elements \\
\hline 1. Capitals & 1. Strategic focus and future & 1. Organizational overview and \\
\hline 1.1 Financial & orientation & external environment \\
\hline 1.2 Manufactured & 2. Connectivity of information & 2. Governance \\
\hline 1.3 Intellectual & 3. Stakeholder relationships & 3. Business model \\
\hline 1.4 Human & 4. Materiality & 4. Risks and opportunities \\
\hline 1.5 Social and relationship & 5. Conciseness & 5. Strategy and resource allocation \\
\hline 1.6 Natural & 6. Reliability and completeness & 6. Performance \\
\hline \multirow[t]{2}{*}{ 2. Value creation } & 7. Consistency and comparability & 7. Outlook \\
\hline & & 8. Basis of presentation \\
\hline
\end{tabular}

Source: (Stent and Dowler, 2015)

\subsection{Motivation of Integrated Reporting}

Black Sun (2014) observed that integrated reporting is vital to businesses and their stakeholders. It can, for example, increase the stakeholders' ability to understand the values of the firm, while also allowing an organization to improve its information management and decision making, develop performance indicators, build relationships with its stakeholders, and enhance cooperation with a reporting team as well as others within the organization. In addition, it has also been 
observed that a company which utilizes integrated reporting will attract a greater proportion of long-term investors compared to short-term investors. The dynamics of integrated reporting, therefore, lead to changes in types of investors (Serafeim, 2015). Meanwhile, the proportion of long-term investors likely increases the importance of the implementation of the integrated reporting (Association of Chartered Certified Accountants [ACCA] 2014). However, this concept focuses on all stakeholders who are interested in the report, even though the investors are the primary focus of these reports. Hence, the annual integrated reports are different from the sustainability reports produced by businesses (PWC, 2014b).

Some organizations have been influenced to take up integrated reporting by internal motivations, such as increased efficiency, reduced costs, and better communication (Eccles \& Saltzman, 2011). The large private European companies have achieved the highest level of integration. The leading industries that have adopted the integrated reporting include financial service sectors, industrial energy infrastructures, energy companies, and mining industries. It is also worth noting that the integrated report goes under various names, such as a sustainability report, but the integrated report is a name that has become the most popular title of organizations' annual reports (Global Reporting Initiative[GRI], 2013). The results of a study by Hanks and Gardiner (2012) on 40 companies operating in South Africa and at the forefront of integrated reporting showed that an effective integration is composed of the following five components. Firstly, the integration needs the involvement of the organization's directors and senior executives at the beginning of the reporting process. Secondly, the integration needs the strategic process of inquiry which helps users to determine the organizational governance structure. Thirdly, drafting the report requires a team that combines many functions within the organization. Fourthly, the integration should be part of a management system. Finally, the companies can use the results of the report to communicate effectively (Hanks \& Gardiner, 2012).

Even though, the integrated reporting is valuable to companies, there are many reasons for not adopting this form. Firstly, the main reason is that some investors still do not see the value of integration. Additionally, investors are concerned about the turmoil integration added to the annual report, which requires policy makers to plan carefully to ensure a successful integration (ACCA, 2014). Secondly, a direction of integrated reporting that will take in the future depends on many factors, such as the scope of the organization's adoption of the report, the reporting quality, and the satisfaction of the investors with the integrated content (KPMG, 2012). Finally, the spread of integrated reporting is also dependent on the region or country including law systems and industries in which the organization is based (Frias-Aceituno et al., 2014; Frias-Aceituno, Rodriguez-Ariza, \& Garcia-Sanchez, 2013a; Tudor-Tiron \& Dragu, 2014)

Overall, integrated reporting is a summary of a company's performance through a holistic overview of both financial and non-financial issues. The guidelines for integrated reporting are currently based on the international integrated reporting framework which determines the composition of the eight elements to be reported: organizational overview and external environment, governance, business models, risks and opportunities, strategies and resource allocation, performance, future outlooks, and basics of presentation. The successful adoption of integrated reporting requires the following components: directors and senior management, strategic processes of inquiry, effective arrangements of the reporting teams, reporting as a part of a new or an existing management system, and the use of the outcomes of the report to communicate corporate performance with their stakeholders more efficiently. In addition, a region or a country including law systems and industries in which the organization is based also plays a significant role in the policy and regulation of the integrated reporting practice. 


\section{METHODOLOGIES}

\subsection{Research Objective}

The objective of this study is to investigate the level and extent to which the IIRC Framework is being applied in the corporate reports of listed companies on the Stock Exchange of Thailand examines explicitly:

(1) The level and extent of integrated financial reporting of listed companies on the Stock Exchange of Thailand.

(2) The effect of industry type on the level of integrated financial reporting of listed companies on the Stock Exchange of Thailand.

\subsection{Research Question}

Since Thai listed companies started to integrate financial reporting into corporate reports in 2015, it has drawn the academic attention. For instance, Boonlua and Phankasem (2016) emphasized the International Integrated Reporting Council (IIRC) framework into the integrated report for companies in Thailand and examined the board of committee responsiveness for the companies' use of the integrated report. Furthermore, Suttipun (2017) investigated the level of integrated reporting related to the six corporate capitals in the annual reports of companies, and tested an effect of the integration on the firm performance. However, they do not consider the content elements of IIRC framework, also do not test the effect of industry type on the level and extent of integrated financial reporting of listed companies which is an effect which determines the integration level. Consequently, the following research questions are developed:

$\mathrm{RQ}_{1}$ : What are the level and extent of integrated financial reporting of listed companies on the Stock Exchange of Thailand?

$\mathrm{RQ}_{2}$ : Whether the industry of the companies determines the level of integrated financial reporting of listed companies on the Stock Exchange of Thailand.

\subsection{Research Hypothesis}

The prior study found a variation of the levels of disclosure in the corporate report across all sectors of the economy. For example, Stanga (1976) found industry type affected disclosure in published annual reports. Additionally, Cooke (1989) found industry type determined on Swedish corporations' report. Cooke (1992) also found the interaction between industry type and corporate disclosure. Likewise, the diffusion of integrated reporting is also dependent on sectors in which the corporation is based (Frias-Aceituno, Rodriguez-Ariza, \& Garcia-Sanchez, 2013b; Frias-Aceituno et al., 2014; Garcia-Sanchez, Rodriguez-Ariza, \& Frias-Aceituno, 2013; Tudor-Tiron \& Dragu, 2014). Hence, the following hypothesis to be tested is:

Hypothesis: There is a significant difference in the level of integrated financial reporting among different industries.

\subsection{Population and Sample}

The population in this study consisted of 462 Thai listed companies. The appropriate average size of a sample group from a population in the hundreds should be $25-30 \%$ (Pongwichai, 2009). Therefore, the sample size of this study is 139 companies, calculated as $30 \%$ of 462 companies. The companies in the sample were chosen by stratified random sampling divided into eight industry 
types. The data were collected from the annual registration statement (Form 56-1) for year-end 2015. This year was chosen because it was the first time that the Securities and Exchange Commission had mandated all listed companies to disclose their corporate social responsibility information on form 56-1.

\subsection{Data Collection and Variable Measurement}

The researchers employed the content analysis approach to quantify the adoption of the International Integrated Reporting Framework in the corporate reporting of the sample organizations. Many researchers applied the content analysis approach to measure corporate disclosures in annual reports. However, the limitation of content analysis is that it provides no indication of the significance the companies attach to each information area (Gray, Rouhy, \& Lavers, 1995). Therefore, the authors constructed the integrated financial reporting items index. The content elements of the International Integrated Reporting Framework were used to determine the level and extent to which integrated financial reporting was applied in previous studies (Herath \& Gunarathne, 2016; Stent \& Dowler, 2015). In the current study, the basic of presentation element is excluded because it is difficult to be measured objectively due to the lack of this information in corporate report. Therefore, the integrated financial reporting index consisted of 34 items across seven categories: organizational overview and external environment (7 items), governance ( 5 items), business model (5 items), risks and opportunities ( 3 items), strategy and resource allocation (4 items), performance ( 7 items), and future outlook ( 3 items). The researchers applied dichotomous scoring to indicate the level of integrated financial reporting. An item scores one if it is mentioned and zero if it is not. Disclosure Index (DI) is computed as follows:

$\mathrm{n} \mathrm{m}$

$$
\mathrm{DI}=\sum \mathrm{di} / \sum \mathrm{di}
$$

$$
\mathrm{i}=1 \quad \mathrm{i}=1
$$

Where;

$\mathrm{di}=1$ if the item is mentioned and 0 if not;

$\mathrm{n}=$ the number of mentioned items;

$\mathrm{m}=$ the maximum number of items;

Values of Disclosure Index are between 0 and $1(0 \leq$ INDEX $\leq 1)$. A value closer to 1 indicates a greater application of the International Integrated Reporting Framework into corporate reporting.

\subsection{Data Analysis}

Descriptive analysis, ANOVA, and t-test were used to analyse the data of this study. Following by the objectives of study, descriptive analysis, including Mean and SD, were used to investigate the extent and level of integrated reporting in corporate reports, while ANOVA and t-test were used to compare the different levels of integrated reporting in corporate reports between companies in different industries.

\section{RESEARCH FINDINGS}

The study collected data in the form of the annual registration statements (Form 56-1) from 139 listed firms on the Stock Exchange of Thailand for year-end 2015 by using the checklist approach. 
The index consisted of 34 items, classified into seven categories based on the International Integrated Reporting Framework.

\subsection{Descriptive Analysis}

Descriptive analysis illustrates the level and extent to which the International Integrated Reporting Framework was adopted by the sample companies on the Stock Exchange of Thailand. As shown in Table 2, it is evident that all eight industries have already adopted at least one of the elements from the International Integrated Reporting Framework. Overall, the sample produced a disclosure index of $0.46(46 \%)$. It can be observed that a value closer to one-half indicated a medium applies the International Integrated Reporting Framework into corporate reporting. The sample companies adopted $\mathrm{OE}$ and $\mathrm{RO}$ elements to a greater degree than the other elements. This shows that these companies placed more emphasis on reporting on their organizational overview and external environment (OE), which focuses more on missions and visions of a company as well as the ownership and operating structure. These elements include explicit explanations of the organization's principle activities, market, products and services, and key quantitative information such as the number of employees, revenues, locations, and significant changes. In addition, the risks and opportunities (RO) element identifies the likelihood of those risks and opportunities occurring, and the steps that management can take to mitigate the risks or exploit the opportunities. Conversely, the sample adopted the strategy and resource allocation (SR) element less than any other elements from the framework, which is possibly because this requires the companies to explain their strategic objectives together with their timeframes and implementation plans, resource allocation plans, and measurement of achievement and outcomes.

Table 2: Descriptive Statistics of the Integrated Financial Reporting Index

\begin{tabular}{|c|c|c|c|c|}
\hline Category & Mean & SD & Max. & $\mathrm{DI}(\%)$ \\
\hline Organizational overview and external environment (OE) & 5.20 & 1.09 & 7 & 74.29 \\
\hline Governance (GV) & 1.16 & 0.38 & 5 & 23.20 \\
\hline Business model (BM) & 3.24 & 0.79 & 5 & 64.80 \\
\hline Risk and opportunities (RO) & 2.18 & 0.69 & 3 & 72.67 \\
\hline Strategy and resource allocation (SR) & 0.18 & 0.43 & 4 & 4.50 \\
\hline Performance (PM) & 2.70 & 0.90 & 7 & 38.57 \\
\hline Future outlook (FO) & 0.86 & 1.13 & 3 & 28.67 \\
\hline Total score & 15.52 & 2.79 & 34 & 45.64 \\
\hline
\end{tabular}

An analysis of Table 3 reveals that the highest score is found in the financial and resource industries, while the technology sector obtained the lowest score. This finding demonstrates a small difference of the level of integrated financial reporting between business industries. In respect of the dissemination of organizational overview and external environment information, the most common items which have been disclosed are elements of the corporate integrated report in 
all sectors. The theme of corporate performance information is in the second place in the consumer products sector, resources sector, services sector, and technology sector. These business industries tend to disclose financial performance that could help investors obtain the desired profits on their investments. The area of business model information is in a second place in the agro and food industries, industrial sector, and property and construction sector. Due to the complexity in business model, they should clearly disclose the corporate business model. That would enable investors and other stakeholders to make their own predictions about the future value creation of the organization. Finally, the governance element is in the second order in the financial industry. Good governance is a vital part of any corporation, both within and beyond the financial sector. The financial institutions play an important role in driving the country's economy where failures in governance can have an effect on the entire financial system and broader economy. They should obviously disclose corporate governance to ensure the efficient operation of financial institutions, transparency and good governance. Nonetheless, there are category variations between business sectors as shown in the following section. 
Table 3: Descriptive Statistics of the Integrated Financial Reporting Scores across Industries

\begin{tabular}{|c|c|c|c|c|c|c|c|c|c|c|c|c|c|c|c|c|}
\hline & \multicolumn{2}{|c|}{ Agro\& Food } & \multicolumn{2}{|c|}{ Consumer } & \multicolumn{2}{|c|}{ Financials } & \multicolumn{2}{|c|}{ Industrials } & \multicolumn{2}{|c|}{$\begin{array}{c}\text { Property \& Cons- } \\
\text { truction }\end{array}$} & \multicolumn{2}{|c|}{ Resources } & \multicolumn{2}{|c|}{ Services } & \multicolumn{2}{|c|}{ Technology } \\
\hline & Mean & SD & Mean & SD & Mean & SD & Mean & SD & Mean & SD & Mean & SD & Mean & SD & Mean & SD \\
\hline $\mathrm{OE}$ & 5.71 & .72 & 5.67 & .98 & 5.73 & .79 & 5.37 & .92 & 4.76 & 1.12 & 5.00 & .77 & 5.11 & 1.21 & 4.36 & 1.43 \\
\hline GV & 2.21 & .42 & 2.16 & .38 & 2.53 & .74 & 2.20 & .41 & 2.12 & .33 & 2.00 & .00 & 2.03 & .33 & 2.00 & .00 \\
\hline $\mathrm{BM}$ & 2.28 & .72 & 2.08 & .66 & 1.93 & .45 & 2.46 & .89 & 2.87 & .76 & 2.45 & .82 & 2.03 & .70 & 2.00 & .77 \\
\hline $\mathrm{RO}$ & 1.85 & .77 & 1.75 & .62 & 2.46 & .63 & 2.12 & .74 & 2.40 & .64 & 2.18 & .60 & 2.19 & .62 & 2.18 & .60 \\
\hline SR & 0.29 & .61 & 0.17 & .38 & 0.67 & .61 & 0.21 & .50 & 0.04 & .20 & 0.09 & .30 & 0.07 & .26 & 0.00 & .00 \\
\hline PM & 2.07 & .61 & 3.08 & .90 & 2.13 & .83 & 2.13 & .93 & 2.45 & .57 & 3.08 & 1.00 & 3.72 & .84 & 2.59 & .60 \\
\hline FO & 0.71 & .99 & 1.17 & 1.33 & 1.60 & 1.29 & 0.67 & 1.00 & 0.88 & 1.12 & 1.45 & 1.36 & 0.63 & 1.00 & 0.00 & 0.00 \\
\hline
\end{tabular}


Table 4: ANOVA Analysis

\begin{tabular}{|c|c|c|c|c|c|c|}
\hline & & Sum of Squares & $\mathrm{df}$ & Mean Square & $\mathrm{F}$ & Sig. \\
\hline \multirow[t]{3}{*}{$\overline{\mathrm{OE}}$} & Between Groups & 24.505 & 7 & 3.501 & 3.233 & .003 \\
\hline & Within Groups & 141.854 & 131 & 1.083 & & \\
\hline & Total & 166.360 & 138 & & & \\
\hline \multirow[t]{3}{*}{ GV } & Between Groups & 3.200 & 7 & .457 & 2.809 & .009 \\
\hline & Within Groups & 21.318 & 131 & .163 & & \\
\hline & Total & 24.518 & 138 & & & \\
\hline \multirow[t]{3}{*}{$\mathrm{BM}$} & Between Groups & 13.654 & 7 & 1.951 & 3.499 & .002 \\
\hline & Within Groups & 73.022 & 131 & .557 & & \\
\hline & Total & 86.676 & 138 & & & \\
\hline \multirow[t]{3}{*}{$\mathrm{RO}$} & Between Groups & 6.187 & 7 & .884 & 2.008 & .059 \\
\hline & Within Groups & 57.669 & 131 & .440 & & \\
\hline & Total & 63.856 & 138 & & & \\
\hline \multirow[t]{3}{*}{ SR } & Between Groups & 4.967 & 7 & .710 & 4.316 & .000 \\
\hline & Within Groups & 21.536 & 131 & .164 & & \\
\hline & Total & 26.504 & 138 & & & \\
\hline \multirow[t]{3}{*}{ PM } & Between Groups & 29.193 & 7 & 4.170 & 6.526 & .000 \\
\hline & Within Groups & 83.714 & 131 & .639 & & \\
\hline & Total & 112.906 & 138 & & & \\
\hline \multirow[t]{3}{*}{$\mathrm{FO}$} & Between Groups & 24.002 & 7 & 3.429 & 2.896 & .008 \\
\hline & Within Groups & 155.121 & 131 & 1.184 & & \\
\hline & Total & 179.122 & 138 & & & \\
\hline
\end{tabular}

\subsection{Comparative Analysis}

Table 4 provides the results of analyses of variance found that the score of integrated financial reporting in each group of industries was different at a statistical significance level of 0.05 in six groups; organizational overview and external environment ( $p$-value $=.003$ ), governance $(p$-value $=.009)$, business model $(p$-value $=.002)$, strategy and resource allocation $(p$ value $=.000)$, performance ( $p$ - value $=.000$ ) and future outlook ( $p$-value $=.008)$, whereas risks and opportunities ( $p$-value $=.059$ ) was insignificant. The ANOVA test of multiple comparisons was utilized - Tukey, at the 0.05 level of confidence as shown in Table 5- to explore how significant the disclosure difference is between each pair of industry across the integrated financial reporting categories. The analysis of the difference between the score of integrated financial reporting in each industry was classified in the pair. The results showed that organizational overview and external environment, business model, strategy and resource allocation, performance and future outlook were found to be significantly different between each pair of sectors. There are significant differences between technology industry with agro \& food industry, and financial industry for the organizational overview and external environment. Moreover, there are significant differences between the industry with service and technology industry for business model. In addition, there are significant differences between the technology and financial industry for strategy and resource allocation. Furthermore, there are significant differences between the property and construction and resources with agro \& food and financial for performance. Also, there are significant differences between the Technology industry with property and construction and financial industry for future outlook.

To test the hypothesis, this study accepted whether there was a significant different level of integrated reporting between the companies in different industries. 
Table 5: Comparative Statistics of the Integrated Financial Reporting Scores across Industries

\begin{tabular}{|c|c|c|c|c|c|c|c|c|c|c|c|c|c|c|c|}
\hline & & \multicolumn{2}{|c|}{$\mathrm{OE}$} & \multicolumn{2}{|c|}{ GV } & \multicolumn{2}{|c|}{$\mathrm{BM}$} & \multicolumn{2}{|c|}{$\mathrm{RO}$} & \multicolumn{2}{|c|}{ SR } & \multicolumn{2}{|c|}{ PM } & \multicolumn{2}{|c|}{$\mathrm{FO}$} \\
\hline & & Diff & Sig. & Diff & Sig. & Diff & Sig. & Diff & Sig. & Diff & Sig. & Diff & Sig. & Diff & Sig \\
\hline \multirow[t]{7}{*}{ Agro \& food } & Cons. products & .05 & 1.00 & .05 & 1.00 & .20 & 1.00 & .18 & 1.00 & .12 & 1.00 & -1.01 & .10 & -.45 & 1.00 \\
\hline & Financials & -.02 & 1.00 & -.32 & 1.00 & .35 & .91 & -.61 & .22 & -.38 & .99 & -.06 & 1.00 & -.89 & .75 \\
\hline & Industrials & .34 & .98 & .01 & 1.00 & -.59 & .28 & -.27 & .93 & .08 & 1.00 & -.39 & .98 & .05 & 1.00 \\
\hline & Prop.\& const. & .95 & .12 & .09 & 1.00 & .09 & 1.00 & -.54 & .23 & .25 & .99 & $-1.01^{*}$ & .00 & -.17 & 1.00 \\
\hline & Resources & .71 & .69 & .21 & .91 & -.17 & 1.00 & -.32 & .93 & .19 & 1.00 & $-1.66^{*}$ & .01 & -.74 & .99 \\
\hline & Services & .60 & .65 & .18 & 1.00 & .25 & .97 & -.33 & .81 & .21 & 1.00 & -.52 & .58 & .08 & 1.00 \\
\hline & Technology & $1.35^{*}$ & .03 & .21 & .91 & .29 & .98 & -.32 & .93 & .29 & .95 & -.75 & .15 & .71 & .41 \\
\hline \multirow[t]{7}{*}{ Cons. products } & Agro \& food & -.05 & 1.00 & -.05 & 1.00 & -.20 & 1.00 & -.11 & 1.00 & -.12 & 1.00 & 1.01 & .10 & .45 & 1.00 \\
\hline & Financials & -.07 & 1.00 & -.37 & .97 & .15 & 1.00 & -.72 & .11 & -.50 & .38 & .95 & .24 & -.43 & 1.00 \\
\hline & Industrials & .29 & .99 & -.04 & 1.00 & -.79 & .06 & -.38 & .75 & -.04 & 1.00 & .66 & .85 & .50 & 1.00 \\
\hline & Prop.\& const. & .91 & .21 & .047 & 1.00 & -.12 & 1.00 & -.65 & .11 & .13 & 1.00 & .00 & 1.00 & .29 & 1.00 \\
\hline & Resources & .67 & .79 & .17 & 1.00 & -.37 & .93 & -.43 & .77 & .08 & 1.00 & -.64 & .98 & -.29 & 1.00 \\
\hline & Services & .56 & .79 & .13 & 1.00 & .05 & 1.00 & -.44 & .56 & .09 & 1.00 & .49 & .98 & .54 & 1.00 \\
\hline & Technology & 1.30 & .06 & .17 & 1.99 & .08 & 1.00 & -.43 & .77 & .17 & .99 & .27 & 1.00 & 1.17 & .28 \\
\hline \multirow[t]{7}{*}{ Financials } & Agro \& food & .02 & 1.00 & .32 & 1.00 & -.35 & .918 & .61 & .22 & .38 & .96 & .06 & 1.00 & .89 & .75 \\
\hline & Cons. products & .07 & 1.00 & .37 & .97 & -.15 & 1.00 & .72 & .11 & .50 & .38 & -.95 & .24 & .43 & 1.00 \\
\hline & Industrials & .36 & .97 & .33 & .98 & $-.94^{*}$ & .01 & .34 & .77 & .46 & .49 & -.33 & 1.00 & .93 & .52 \\
\hline & Prop.\& const. & .97 & .09 & .41 & .81 & -.27 & .96 & .07 & 1.00 & .63 & .04 & $-.95^{*}$ & .02 & .72 & .92 \\
\hline & Resources & .73 & .64 & .53 & .34 & -.52 & .65 & .28 & .96 & .58 & .13 & $-1.59^{*}$ & .01 & .15 & 1.00 \\
\hline & Services & .62 & .58 & .50 & .51 & -.10 & 1.00 & .28 & .89 & .59 & .07 & -.459 & .95 & .97 & .42 \\
\hline & Technology & $1.37^{*}$ & .03 & .53 & .34 & -.07 & 1.00 & .28 & .96 & .67 & .03 & -.68 & .48 & $1.60^{*}$ & .01 \\
\hline
\end{tabular}


Table 5: Comparative Statistics of the Integrated Financial Reporting Scores across Industries (Cont...)

\begin{tabular}{|c|c|c|c|c|c|c|c|c|c|c|c|c|c|c|c|c|c|}
\hline & & \multicolumn{2}{|c|}{ OE } & \multicolumn{2}{|c|}{ GV } & \multicolumn{2}{|c|}{$\mathrm{BM}$} & \multicolumn{2}{|c|}{ RO } & \multicolumn{2}{|c|}{ SR } & \multicolumn{2}{|c|}{ PM } & \multicolumn{2}{|c|}{ FO } & \multicolumn{2}{|c|}{ TOTAL } \\
\hline & & Diff & Sig. & Diff & Sig. & Diff & Sig. & Diff & Sig. & Diff & Sig. & Diff & Sig. & Diff & Sig & Diff & Sig \\
\hline \multirow[t]{7}{*}{ Industrials } & Agro \& food & -.34 & .98 & -.01 & 1.00 & .28 & .92 & .27 & .93 & -.08 & 1.00 & .39 & .98 & -.05 & 1.00 & .77 & .99 \\
\hline & Cons. products & -.29 & .99 & .04 & 1.00 & .06 & .41 & .38 & .75 & .04 & 1.00 & -.63 & .85 & -.50 & 1.00 & -.17 & 1.00 \\
\hline & Financials & -.36 & .97 & -.33 & .98 & .01 & .89 & -.34 & .77 & -.46 & .49 & .33 & 1.00 & -.93 & .52 & -1.15 & .90 \\
\hline & Prop.\& const. & .62 & .44 & .09 & 1.00 & .04 & .74 & -.28 & .83 & .17 & .99 & -.62 & .20 & -.21 & 1.00 & .44 & 1.00 \\
\hline & Resources & .38 & .98 & .21 & .46 & .78 & .50 & -.06 & 1.00 & .12 & 1.00 & -1.27 & .06 & -.79 & .96 & -.99 & .97 \\
\hline & Services & .26 & .99 & .17 & $.97^{*}$ & .00 & .93 & -.06 & 1.00 & .13 & 1.00 & -.13 & 1.00 & .04 & 1.00 & 1.25 & .72 \\
\hline & Technology & 1.01 & .14 & .21 & $.46^{*}$ & .03 & 1.00 & -.06 & 1.00 & .21 & .81 & -.36 & 1.00 & .67 & .10 & 2.60 & .16 \\
\hline \multirow[t]{7}{*}{ Prop.\& const. } & Agro \& food & -.95 & .12 & -.09 & 1.00 & 1.00 & .92 & .54 & .23 & -.25 & .99 & $1.01^{*}$ & .00 & .17 & 1.00 & .34 & 1.00 \\
\hline & Cons. products & -.91 & .21 & -.05 & 1.00 & 1.00 & .41 & .65 & .11 & -.13 & 1.00 & -.00 & 1.00 & -.29 & 1.00 & -.60 & 1.00 \\
\hline & Financials & -.97 & .09 & -.41 & .81 & .96 & .89 & -.07 & 1.00 & -.63 & .04 & $.95^{*}$ & .02 & -.72 & .92 & -1.59 & .62 \\
\hline & Industrials & -.62 & .44 & -.09 & 1.00 & .04 & .74 & .28 & .83 & -.17 & .99 & .62 & .20 & .21 & 1.00 & -.44 & 1.00 \\
\hline & Resources & -.24 & 1.00 & .12 & .91 & .98 & .50 & .22 & .99 & -.05 & 1.00 & -.65 & .86 & -.57 & 1.00 & -1.43 & .82 \\
\hline & Services & -.35 & .93 & .08 & 1.00 & .99 & .93 & .21 & .94 & -.03 & 1.00 & .49 & .40 & .25 & 1.00 & .81 & .968 \\
\hline & Technology & .40 & .97 & .12 & .91 & 1.00 & 1.00 & .22 & .99 & .04 & 1.00 & .26 & 1.00 & $.88^{*}$ & .02 & 2.12 & .38 \\
\hline \multirow[t]{7}{*}{ Resources } & Agro \& food & -.71 & .69 & -.21 & .91 & 1.00 & .92 & .32 & .93 & -.19 & 1.00 & $1.66^{*}$ & .01 & .74 & .99 & 1.77 & .73 \\
\hline & Cons. products & -.67 & .79 & -.17 & 1.00 & .93 & .41 & .43 & .77 & -.08 & 1.00 & .64 & .98 & .29 & 1.00 & .83 & 1.00 \\
\hline & Financials & -.73 & .64 & -.53 & .34 & .65 & .89 & -.28 & .96 & -.58 & .13 & $1.59^{*}$ & .01 & -.15 & 1.00 & -.16 & 1.00 \\
\hline & Industrials & -.38 & .98 & -.21 & .46 & .78 & .74 & .06 & 1.00 & -.18 & 1.00 & 1.27 & .06 & .79 & .96 & .99 & .97 \\
\hline & Prop.\& const. & .24 & 1.00 & -.12 & .91 & .98 & .50 & -.22 & .99 & .05 & 1.00 & .65 & .86 & .57 & 1.00 & 1.43 & .82 \\
\hline & Services & -.11 & 1.00 & -.04 & 1.00 & .77 & .93 & -.00 & 1.00 & .02 & 1.00 & 1.13 & .12 & .82 & .93 & 2.24 & .29 \\
\hline & Technology & .64 & .84 & .00 & 1.00 & .84 & 1.00 & .00 & 1.00 & .09 & 1.00 & .91 & .44 & 1.45 & .14 & $3.55^{*}$ & .05 \\
\hline
\end{tabular}


Table 5: Comparative Statistics of the Integrated Financial Reporting Scores across Industries (Cont...)

\begin{tabular}{|c|c|c|c|c|c|c|c|c|c|c|c|c|c|c|c|c|c|}
\hline & & \multicolumn{2}{|c|}{$\mathrm{OE}$} & \multicolumn{2}{|c|}{ GV } & \multicolumn{2}{|c|}{$\mathrm{BM}$} & \multicolumn{2}{|c|}{$\mathrm{RO}$} & \multicolumn{2}{|c|}{ SR } & \multicolumn{2}{|c|}{ PM } & \multicolumn{2}{|c|}{$\mathrm{FO}$} & \multicolumn{2}{|c|}{ TOTAL } \\
\hline & & Diff & Sig. & Diff & Sig. & Diff & Sig. & Diff & Sig. & Diff & Sig. & Diff & Sig. & Diff & Sig & Diff & Sig \\
\hline \multirow[t]{7}{*}{ Services } & Agro \& food & -.60 & .65 & -.18 & 1.00 & -.25 & .97 & .39 & .81 & -.21 & 1.00 & .52 & .58 & -.08 & 1.00 & -.48 & 1.00 \\
\hline & Cons. products & -.56 & .79 & -.13 & 1.00 & -.05 & 1.00 & .44 & .56 & -.09 & 1.00 & -.49 & .98 & -.54 & 1.00 & -1.42 & .80 \\
\hline & Financials & -.62 & .58 & -.50 & .51 & .10 & 1.00 & -.28 & .89 & -.59 & .07 & .46 & .95 & -.97 & .42 & -2.40 & .11 \\
\hline & Industrials & -.26 & .99 & -.17 & .97 & $-.84^{*}$ & .00 & .06 & 1.00 & -.13 & 1.00 & .13 & 1.00 & -.04 & 1.00 & -1.25 & .72 \\
\hline & Prop.\& const. & .35 & .93 & -.08 & 1.00 & -.16 & .99 & -.21 & .94 & .03 & 1.00 & -.49 & .40 & -.25 & 1.00 & -.81 & .96 \\
\hline & Resources & .11 & 1.00 & .04 & 1.00 & -.42 & .77 & .00 & 1.00 & -.02 & 1.00 & -1.13 & .12 & -.82 & .93 & -2.24 & .29 \\
\hline & Technology & .75 & .48 & .04 & 1.00 & .04 & 1.00 & .00 & 1.00 & .07 & .99 & -.23 & 1.00 & .63 & .09 & 1.30 & .88 \\
\hline \multirow[t]{7}{*}{ Technology } & Agro \& food & $-1.35^{*}$ & .03 & -.21 & .91 & -.29 & .98 & .32 & .93 & -.29 & .95 & .75 & .15 & -.71 & .41 & -1.78 & .76 \\
\hline & Cons. products & -1.30 & .06 & -.17 & 1.00 & -.08 & 1.00 & .43 & .77 & -.17 & .99 & -.27 & 1.00 & -1.17 & .28 & -2.71 & .24 \\
\hline & Financials & $-1.37^{*}$ & .03 & -.53 & .34 & .07 & 1.00 & -.28 & .96 & $-.67^{*}$ & .03 & .68 & .48 & $-1.6^{*}$ & .01 & $-3.70^{*}$ & .02 \\
\hline & Industrials & -1.01 & .14 & -.21 & .46 & $-.88^{*}$ & .03 & .06 & 1.00 & -.21 & .81 & .36 & 100. & -.67 & .10 & -2.55 & .16 \\
\hline & Prop.\& const. & -.40 & .97 & -.12 & .91 & -.20 & 1.00 & -.22 & .99 & -.04 & 1.00 & -.26 & 1.00 & $-.88^{*}$ & .02 & -2.12 & .38 \\
\hline & Resources & -.64 & .84 & .00 & 1.00 & -.45 & .84 & .00 & 1.00 & -.09 & 1.00 & -.91 & .44 & -1.45 & .14 & $-3.54^{*}$ & .05 \\
\hline & Services & -.75 & .48 & -.04 & 1.00 & -.04 & 1.00 & -.00 & 1.00 & -.07 & .99 & .23 & 1.00 & -.63 & .09 & -1.30 & .88 \\
\hline
\end{tabular}




\section{CONCLUSIONS AND DISCUSSIONS}

Based on two main research questions of this study, the results found that integrated financial reporting practices of the companies listed on the Stock Exchange of Thailand vary according to the industries in which the firms operate. Companies from all industries provided the majority of their integrated financial reporting on organizational overview and external environment (OE), whereas the least reported element across all industries was strategy and resource allocation (SR). This finding illustrates diversities in the reporting of the primary elements across the eight sectors. For instance, the financial industry had the highest scores for reporting on governance (GV), risks and opportunities (RO), strategy and resource allocation (SR), and future outlook (FO). This is likely due to that fact that the financial industry is having more disclosure regulations than the other industries. The resource industry focused considerably more on performance (PM) compared to the other industries. Consequently, the performance of this industry revealed more effects on the economy, society, and environment. The agro and food industry focused on organizational overview and external environment (OE), while the business model was a primary area of focus in the industrial sector and resources industry.

The results of the level and extent of integrated reporting in this study were consistent with that of Suttipun (2017) who found the listed companies in the SET provided at least one of the elements from the IIRF in their reports. This is because if companies have a reputation for reporting much information about their actions and activities, they will obtain more benefits and values from their stakeholders, whose expectations they meet and whose trusts they gain. Moreover, companies which provide much information to their stakeholders in order to decrease information asymmetry are likely to optimize their financing costs, and thus improve their firm values (Frias-Aceituno et al., 2014). Therefore, having corporate integrated reporting can bring benefits and image to companies. On the other hand, the present study found the significant level of integrated reporting between companies in different industries. The result at this point was similar to the previous studies of Jamal and Ghani (2016); Abdullah, Husin, and Nor (2017); and Nurunnabi, Hossain, and Hossain (2001). It is because, in different industries, there were different contents and stakeholder types; therefore, the level including the extent of integrated reporting would be different.

The findings regarding the integrated reporting practices of listed companies on the Stock Exchange of Thailand will be useful for corporations intending to adopt the integrated reporting principles as the study provides several contributions to accounting studies, accounting practices, and regulations. The study also suggests that the Stock Exchange of Thailand which monitors the disclosures of the listed firms should improve their reviews of contents disclosed in corporate reporting based on the International Integrated Reporting Framework. The study can develop knowledge and understanding about Thailand which represents an emerging economic country. Finally, the findings can contribute useful knowledge to investors, shareholders, and creditors who consider integrated reporting when making investment decisions and may lead to improvements in the Thai regulations related to integrated reporting with benefits for people, planet, and profit.

Some limitations of the study were noted; the researchers focused on summarizing the features of integrated financial reporting of the sample. Future studies could investigate the determinants of the practices of integrated financial reporting and consequence as well. However, this study is significant because it provides fundamental information for the development of integrated financial reporting in Thailand which is an emerging economic country. 


\section{REFERENCES}

Abdullah, N. W., Husin, N. M., \& Nor, M. M. (2017). An exploratory study of integrated reporting: A case of public listed companies in Southeast Asia. International Journal of Applied Business and Economic Research, 15(21), 199-205.

Abeysekera, I. (2010). The influence of board size on intellectual capital disclosures by Kenyan listed firms. Journal of Intellectual Capital, 11(4), 504-518.

Abeysekera, I. (2013). A template for integrated reporting. Journal of Intellectual Capital, 14(2), 227245.

Association of Chartered Certified Accountants. (2014). Understanding investors: directions for corporate reporting. Retrieved from http://www.accaglobal.com/ content/dam/acca/global/PDF-technical/financial-reporting/pol-afb-ui02.pdf

Aujirapongpan, S., \& Chanatup, S. (2015). Integrated Reporting: New Dimension of Firms' Performance Reporting. AU-GSB e-JOURNAL, 8(1), 51-60.

Black Sun. (2014). Realizing the benefits: The impact of integrated reporting. Retrieved from http://integratedreporting.org/wp-content/uploads/2014/09/

IIRC.Black_.Sun_.Research.IR_.Impact.Single.pages.18.9.14.pdf

Boonlua, S., \& Phankasem, S. (2016). Engagement in integrated reporting: evidence from the international integrating reporting council adoption framework. Journal of Business and Retail Management Research, 10(3), 126-136.

Cooke, T. E. (1989). Disclosure in the Corporate Annual Reports of Swedish Companies. Accounting and Business Research, 19(74), 113.

Cooke, T. E. (1992). The impact of size, stock market listing and industry type on disclosure in the annual report of Japanese listed corporations. Accounting and Business Research, 22(87), 229.

Demirel, B., \& Erol, I. (2016). Investigation of integrated reporting as a new approach of corporate reporting. International Journal of Business and Social Research, 6(10), 32-46.

Eccles, R. G., \& Saltzman, D. (2011). Achieving sustainability through integrated reporting. Stanford Social Innovation Review, 9(3), 56-61.

Eccles, R. G., \& Serafeim, G. (2015), Corporate and Integrated Reporting: A Functional Perspective. Chapter 9 in Corporate Stewardship: Achieving Sustainable Effectiveness, edited by Ed Lawler, Sue Mohrman, and James O'Toole, Greenleaf.

Frias-Aceituno, J. V., Rodriguez-Ariza, L., \& Garcia-Sanchez, I. M. (2013a). The Role of the Board in the Dissemination of Integrated Corporate Social Reporting. Corporate Social Responsibility and Environmental Management, 20(4), 219-233.

Frias-Aceituno, J. V., Rodriguez-Ariza, L., \& Garcia-Sanchez, I. M. (2014). Explanatory factors of integrated sustainability and financial reporting. Business strategy and the environment, 23(1), 56-72.

Frias-Aceituno, J. V., Rodriguez-Ariza, L., \& Garcia-Sánchez, I. M. (2013b). Is integrated reporting determined by a country's legal system? An exploratory study. Journal of Cleaner Production, 44, 45-55.

Garcia-Sanchez, I.-M., Rodriguez-Ariza, L., \& Frias-Aceituno, J.-V. (2013). The cultural system and integrated reporting. International Business Review, 22(5), 828-838.

Global Reporting Initiative. (2013). The sustainability content of integrated report - a survey of pioneers. Amsterdam: Global Reporting Initiative.

Graham, M. (2014). EY's excellence in integrated reporting awards 2014. Retrieved from https://www.ey.com/Publication/vwLUAssets/EY-Excellence-In-Integrated-Reporting2014/\%24FILE/EY-Excellence-In-Integrated-Reporting-2014.pdf 
Gray, R., Kouhy, R., \& Lavers, S. (1995). Corporate social and environmental reporting: a review of the literature and a longitudinal study of UK disclosure. Accounting, Auditing \& Accountability Journal, 8(2), 47-77.

Hanks, J., \& Gardiner, L. (2012). Integrated reporting: lessons from the South African experience. Retrieved from https://openknowledge.worldbank.org/bitstream/handle/10986/

11052/667570BRI00PUB0O0250IntegrReporting.pdf?sequence=1\&isAllowed=y

Herath, R., \& Gunarathne, N. (2016). Assessing the gap between integrated reporting and current integrated corporate reporting practice: A proposed checklist. Paper presented at the 11 th Faculty of Management Studies and Commerce (FMSC) Research Symposium, Sri Lanka.

Hughen, L., Lulseged, A., \& Upton, D. R. (2014). Improving stakeholder value through sustainability and integrated reporting. The CPA Journal, 84(3), 57.

International Integrated Reporting Committee . (2013a). Basis for conclusions International< IR $>$ Framework. Retrieved from http://integratedreporting.org/

wp-content/uploads/2013/12/13-12-08-Basis-for-conclusions-IR.pdf

International Integrated Reporting Committee . (2013b). Consultation draft of the International< IR> framework. Retrieved from http://www.rjnet.nl/Documents/

Overige \%20publicaties/IIRC\%20Consultation\%20Draft $\% 20$ of $\% 20$ the $\% 20$ International $\% 20 \mathrm{IR} \% 20 \mathrm{Fr}$ amework.pdf

Institute of Singapore Chartered Accountants , \& National University of Singapore [NUS]. (2014). ISCA-NUS integrated reporting survey 2014. Retrieved from https://isca.org.sg/media/775709/isca-nus-integrated-reporting-survey-2014.pdf

Integrated Reporting Committee . (2011). Framework for integrated reporting and the integrated report. Discussion Paper. Retrieved from

http://www.sustainabilitysa.org/Portals/0/IRC\%20of\%20SA\%20Integrated \%20Reporting\%2 0Guide\%20Jan\%2011.pdf

International Federation of Accountants . (2012). Investor Demand for Environmental, Social, and Governance Disclosures: Implications for Professional Accountants in Business. NY: International Federation of Accountants.

Jamal, J., \& Ghani, E. K. (2016). Integrated reporting practices among real property listed companies in Malaysia. Malaysian Accounting Review, 15(1), 251-274.

KPMG. (2012). Integrated Reporting: Performance Insight Through Better Business Reporting (Issue 2). Retrieved from http://integratedreporting.org/wp-content/uploads/2012/06/

KPMG-Integrated-Reporting-Performance-Insight-Through-Better-Business-Reporting-Issue-2.pdf

Lynch, M. F., Lynch, N., \& Casten, D. (2014). The expanding use of sustainability reporting. The CPA Journal, March, 18-24.

Main, N., \& Hespenheide, E. (2012). The integrated reporting: The new big picture. Deloitte Review(10), 124-137.

Nurunnabi, M., Hossain, M., \& Hossain, L. (2001). Intellectual capital reporting in a South Asian country :evidence from Bangladesh .Journal of Human Resource Costing \& Accounting, 15(3), 196-231.

Orens, R., \& Lybaert, N. (2013). Disclosure of Non-Financial Information: Relevant to Financial Analysts?. Review of Business and Economic Literature, 58(4), 375-406.

Pongwichai, S. (2009). The statistical analysis (22 ed.). Bangkok, Thailand: Chulalongkorn University.

PWC (2014a). The state of integrated reporting in Malaysia. Retrieved from https://www.pwc.com/my/en/assets/publications/the-state-of-integrated-reporting-inmalaysia.pdf 
PWC (2014b). Value creation: The journey continues a survey of JSE Top-40 companies' integrated reports. Retrieved from https://www.pwc.co.za/en/assets/pdf/integrated-reportingsurvey-2014.pdf

Serafeim, G. (2015). Integrated reporting and investor clientele. Journal of Applied Corporate Finance, 27(2), 34-51.

Stanga, K. G. (1976). "Disclosure in published annual reports. Financial Management, 5(4), 42-52.

Stent, W., \& Dowler, T. (2015). Early assessments of the gap between integrated reporting and current corporate reporting. Meditari Accountancy Research, 23(1), 92-117. doi:10.1108/medar02-2014-0026

Suttipun, M. (2017). The effect of integrated reporting on corporate financial performance: Evidence from Thailand. Corporate Ownership and Control, 15(1), 133-142.

Tilley, C. (2012). Corporate reporting needs new approach. Financial Management, November, 65.

Tudor-Tiron, A., \& Dragu, I. (2014). From sustainability to integrated reporting-the political perspective of institutional theory. Studia Universitatis Babes-Bolyai, 59(2), 20.

Velte, P. (2014). Improving corporate governance quality though modern controlling - Integrated reporting in the german two tier system. Business and Economics Journal, 5(1), 1-5. 